\title{
Receiver Operating Characteristic Curve Analysis May be Helpful to Study the Prognostic Value of miR-155 in B-Cell Non-Hodgkin Lymphoma
}

\author{
Işlem Karakteristik Eğrisi Analizi B-Hücre Non-Hodgkin Lenfomada miR-155'in Prognostik \\ Değerini Çalışmada Yardımcı Olabilir
}

Long Su

The First Hospital of Jilin University, Department of Hematology, Changchun, China

To the Editor,

Aberrant expression of microRNA (miR-155) has been reported previously in several hematological malignancies $[1,2,3,4]$. Recently, Bedewy et al. [5] published their excellent findings in this journal. They reported that miR-155 expression was significantly upregulated in patients with B-cell non-Hodgkin lymphoma (NHL) compared with normal controls. In patients with B-cell NHL, a high level of miR-155 expression was associated with the presence of B symptoms, involvement of extranodal sites, and high Eastern Cooperative Oncology Group score. In patients with diffuse large B-cell lymphoma (DLBCL), high miR-155 levels were related to non-germinal B-cell-like type and higher International Prognostic Index scores. High miR-155 expression was also associated with inferior event-free survival. Accordingly, the authors concluded that miRNA-155 might be a potential biomarker of prognosis and monitoring in B-cell NHL, and especially that of the DLBCL type [5].

Receiver operating characteristic (ROC) curve analysis is a graphical plot that illustrates the diagnostic ability of a binary classifier system as its discrimination threshold is varied. The best cutoff value can be calculated by ROC analysis for continuous variables to predict dichotomous variables with the best sensitivity and specificity. In Bedewy et al.'s [5] study, the patients were divided into high-expression and low-expression groups based on the median level of miR-155 relative expression units. I wonder if the median value of miR-155 expression level in this study was the cutoff value with the best sensitivity and specificity between patients and normal controls by ROC analysis. Similarly, in patients with B-cell NHL, whether there is another cutoff value that is associated with clinical stage, treatment response, long-term outcomes, and so on remains to be determined.

Keywords: Non-Hodgkin lymphoma, miR-155, Prognostic value

Anahtar Sözcükler: Non-Hodgkin lenfoma, miR-155, Prognostik değer

Conflict of Interest: The authors of this paper have no conflicts of interest, including specific financial interests, relationships, and/or affiliations relevant to the subject matter or materials included.

\section{References}

1. Jones K, Nourse JP, Keane C, Bhatnagar A, Gandhi MK. Plasma microRNA are disease response biomarkers in classical Hodgkin lymphoma. Clin Cancer Res 2014;20:253-264.

2. Wallace $J A$, Kagele $D A$, Eiring $A M$, Kim $C N$, Hu R, Runtsch MC, Alexander M, Huffaker TB, Lee SH, Patel AB, Mosbruger TL, Voth WP, Rao DS, Miles RR, Round JL, Deininger MW, O'Connell RM. miR-155 promotes FLT3-ITDinduced myeloproliferative disease through inhibition of the interferon response. Blood 2017;129:3074-3086.

3. Alizadeh AA, Eisen MB, Davis RE, Ma C, Lossos IS, Rosenwald A, Boldrick JC, Sabet H, Tran T, Yu X, Powell JI, Yang L, Marti GE, Moore T, Hudson J Jr, Lu L, Lewis DB, Tibshirani R, Sherlock G, Chan WC, Greiner TC, Weisenburger DD, Armitage JO, Warnke R, Levy R, Wilson W, Grever MR, Byrd JC, Botstein D, Brown PO, Staudt LM. Distinct types of diffuse large B-cell lymphoma identified by gene expression profiling. Nature 2000;403:503-511.

4. Marcucci G, Maharry KS, Metzeler KH, Volinia S, Wu YZ, Mrózek K, Nicolet D, Kohlschmidt J, Whitman SP, Mendler JH, Schwind S, Becker H, Eisfeld AK, Carroll AJ, Powell BL, Kolitz JE, Garzon R, Caligiuri MA, Stone RM, Bloomfield CD. Clinical role of microRNAs in cytogenetically normal acute myeloid leukemia: miR-155 upregulation independently identifies high-risk patients. J Clin Oncol 2013;31:2086-2093.

5. Bedewy AML, Elmaghraby SM, Shehata AA, Kandil NS. Prognostic value of miRNA-155 expression in B-cell non-Hodgkin lymphoma. Turk J Hematol 2017;34:207-212. 